UDC 82-344

DOI: $10.26565 / 2227-1864-2019-81-12$

\title{
Fantasy semantic field: problems of definition
}

\author{
Nataliya Ivanova \\ the Assistant Professor of School of the Russian Language, \\ World Literature and Methods of Teaching, \\ Ph.D. in Philology, Bohdan Khmelnitsky National University of Cherkassy; \\ e-mail: nathal3@ukr.net; https://orcid.org/0000-0002-9558-9764 \\ Olga Ryzhchenko \\ the Assistant Professor of Language Training department, \\ Ph.D. in Philology, Kharkiv National University of Radio Electronics; \\ e-mail: eradis80@rambler.ru; https://orcid.org/0000-0003-1693-6121
}

Іванова Н. П., Рижченко О. С. Семантичне поле фентезі: проблеми визначення

На сучасному етапі розвитку літератури «чистий» жанр зникає, поступаючись місцем різним утворенням, що поєднують у собі ознаки двох і більше жанрів. Одним із таких, відносно «нових», літературних явищ є фентезі, навколо якого постийно ведуться дискусії. Підвищений інтерес до нього з боку літературознавців може бути пояснений постійною динамікою фентезі, що призводить до розширення його тематичних різновидів, а відтак і до розширення читацького кола (воно охоплює читачів різних вікових груп та різного соціального статусу).

Фентезі закономірно сформувалось у самостійну галузь в межах фантастики вже у другій половині XX століття. Хоча, в дійсності, має витоки із багатовікової традиції фантастичного (міфо-фольклорна традиція, середньовіччя, бароко, традиції готичного роману, романтизм та модернізм), в якій запозичувало різноманітні способи відтворення дійсності.

Незважаючи на велику кількість досліджень, присвячених різним аспектам та проблемам вивчення фентезі (Дрієр С., Фредріксон Н., Лугова Є., Маркова Т., Толкачова В., Хоруженко Т. та ін.), на сьогодні немає чіткого визначення даного поняття. Більшість літературознавців називають фентезі жанром, окреслюючи при цьому стійкі складники його змісту (фантастичну реальність, орієнтовану на міфо-фольклорну традицію, наявність авантюрної інтриги, дійових осіб 3 магічними здібностями, наявність магічних артефактів, протистояння злу в глобальному масштабі).

Ми вважаємо, що фентезі - це мета-жанр, який має свою стійку структуру моделювання світу та об'єднує спільним предметом художнього зображення різноманітні жанри в літературі та в інших видах мистецтва. Проте на сьогодні для ствердження того, що фентезі - мета-жанр, не вистачає однієї важливої складової - це збереження структурносемантичного ядра упродовж кількох епох. Хоча ми можемо стверджувати, що фентезійні елементи вже чітко промальовувались і в модернізмі.

Ключові слова: жанр; мета-жанр; міфо-фольклорна традиція; фантастика; фентезі

Иванова Н. П., Рыжченко О. С. Семантическое поле фэнтези: проблемы определения

На современном этапе развития литературы жанр в «чистом» виде исчезает, уступая место различным образованиям, сочетающим в себе признаки двух и более жанров. Одним из таких относительно «новых» литературных явлений, вокруг которого постоянно ведутся дискуссии, становится фэнтези. Повышенный интерес к нему со стороны литературоведов можно объяснить постоянной динамикой самого фэнтези, что приводит к увеличению его тематических разновидностей, и, как следствие, к расширению читательского круга (охватывающего читателей разных возрастов и разного социального статуса).

Фэнтези закономерно сформировалось в отдельный жанр в рамках франтастики уже во второй половине XX века. Хотя, на самом деле, фэнтези уходит корнями в многовековую традицию фантастического (мифо-фольклорную традицию, средневековье, барокко, традиции готического романа, романтизм и модернизм), из которой заимствовало различные способы воспроизведения действительности.

Несмотря на большое количество исследований, посвященных различным аспектам и проблемам изучения фэнтези (Дриер С., Фредриксон Н., Луговая Е., Маркова Т., Толкачева В., Хоруженко Т. и др.), на сегодня нет четкого определения данного понятия. Большинство литературоведов называют фэнтези жанром, указывая при этом на устойчивые составляющие его содержательной стороны (фантастическую реальность, ориентированную на мифоо-фольклорную традицию, наличие авантюрной интриги, действующих лиц с магическими способностями, наличие магических артефактов, противостояние злу в глобальном масштабе).

Мы считаем, что фэнтези это мета-жанр, который имеет свою устойчивую структуру моделирования мира и объединяет общим предметом художественного изображения различные жанры в литературе и в других видах искусства. Однако на сегодня для утверждения того, что фэнтези - это мета-жанр, не хватает одной важной составляющей - сохранения структурно-семантического ядра на протяжении нескольких эпох. Хотя мы можем утверждать, что фэнтезийные элементы уже четко прорисовывались и в модернизме.

Ключевые слова: жанр; мета-жанр; мифо-фольклорная традиция; фантастика; фэнтези

Ivanova N., Ryzhchenko O. Fantasy semantic field: problems of definition

At the present stage of the development of literature the "pure" genre disappears, giving way to different entities that combine characteristic features of two or more genres. One of these relatively "new" literary phenomena is fantasy, ongoing discussions keep going around. The increased interest in it by literary critics may be explained by the constant dynamics of fantasy, which leads to the expansion of its thematic varieties, and hence to the expansion of the reader's circle (it covers readers of different age groups and different social status). 
Fantasy naturally formed into an independent branch within the limits of speculative fiction in the second half of the twentieth century. In fact, it has origins in the centuries-old tradition of the fantastic (mythical folklore tradition, Medieval, baroque, traditions of the Gothic novel, romanticism and modernism), where it borrowed various ways of reproduction of reality.

Despite the large quantity of studies devoted to various aspects and problems of the study of fantasy (S. Dreier, N. Fredrickson, E. Lugovaya, T. Markova, V. Tolkachova, T. Khoruzhenko etc.), there is no clear definition of this concept. Most literary scholars call fantasy a genre, outlining the persistent components of its content (mythological basis, adventure intrigue, the division of the heroes into possessing superpowers, the presence of magical artefacts, opposition to the evil on a global scale).

We believe that fantasy is a meta-genre that has its own stable structure of modeling the world and brings together a diverse array of genres in literature and other arts as a common object of artistic representation. However, today to assert that fantasy is a metagenre, lacks one important component - the preservation of the structural semantic nucleus over several eras. Although we can assert that fantasy elements have already been clearly depicted in modernism.

Keywords: fantasy; genre; meta-genre; mythology and folklore tradition; speculative fiction

Introduction. The interest in the fantastic is typical for all ages, since human nature possesses the obsession with the unknown and the inexplicable. The routs of the fantastic lies in mythological eras and now they are externalized in the folklore poetic environment as there appeared the first artistic forms of speculative fiction, as a consequence, the folklore translates them into all subsequent historical and cultural epochs. Therefore, the first problem of studying fantasy can be defined as a historical problem. It is associated with the identification of the main aspects and characteristics of creative dynamics, the specifics of the formation and development of fantastic forms in the periods predating modernism.

It still remains disputable the problem of definition of fantasy and its characteristic features which allow to combine the works of fantasy. The analyses of latest literary works shows that different features are defined as typical for fantasy fiction.

Literature Review. Fantasy which has become rather popular in the last 50 years has attracted a lot of attention of modern literary scholars and critics. A large variety of problems connected with it are examined in their works. First of all, it is still not clear if fantasy must be considered to be a genre or subgenre or even a "transgeneric", "intergeneric" or "multigeneric" category [32: 10]. Most researchers define fantasy as a genre, not taking into account the fact that it has overgrown this category. In this connection, Stephanie Dreier [5], E. A. Lugovaya [21], T. N. Markova [22], V. S. Tolkacheva [33] define fantasy as a genre.

For example, in her thesis Stephanie Dreier defines fantasy fiction as "an independent literary genre with a distinct set of thematic and structural features, $\langle\ldots\rangle$ comprised of narratives in which the violation of natural laws, otherwise known as the supernatural component, is indispensable to the integrity of the narrative" [5:26]. The author also points out that "fantasy differs from other subcategories of supernatural literature by its treatment of the imaginary narrative space. <Moreover, > in fantasy fiction, by way of contrast, the narrative is embedded in the supernatural: it tells a story that could have happened only within the unique narrative reality that constitutes the described secondary world - a unique narrative reality that is determined the character of its supernatural elements" [5: 26-27] (for further information please refer to [1]).

(C) Іванова Н. П., Рижченко О. С.
We do not agree with the author who thinks that fantasy is a subcategory of supernatural literature but points out that fantasy is a meta-genre as fantastic elements were typical for other literary genres rather than subgenre which has its roots in supernatural. From our point of view, the supernatural is a peculiar feature of speculative fiction.

However, there exist other opinions. For example, Juta Steinseifer-Szabo views "fantasy not primarily as a genre, but as a mode of responding to the unspeakable traumata and conflicts of modernity that cannot be communicated in realist fiction" [31]. Paula M. Zaja examines fantasy from another point of view - through the mirror of postmodern defining it as "a mode of writing which uses imagination and metaphor to revise reality in a way that reflects and confronts what we experience in our daily lives" [35: 1]. In other words, within fantasy researchers see a way of modeling the artistic world, a specific way of writing. As we understand it, this special way is a characteristic feature of many genres. In our work we will agree with the latter and stay the ground that fantasy is a meta-genre as it was described and proved in the works of well-knows Slavic literary scholars.

From another point of view, fantasy can be considered to be not only a work of fiction to entertain readers but also a very useful resource to solve a variety of different problems. Fantasy is examined in tight connection with rhetoric in the work by Abigail Linhardt who points out that "There is no one place for truth and meaning to be told and no expiration date for the need of imagination and creativity. As humankind, we have a right to dream and learn through creativity if that is our way. That is what fantasy tells us. <..> Over the years, fantasy and creative writing have been the outlet for the most taboo or passionate of beliefs to be discussed" [19: 5-6]. "Fantasy literature, in which magic is ontologically affirmed - often together with the affirmation of medieval, ancient, or alternative forms of social and economic organization, provides a unique space in which and with which to think through classical theorists of religion critically" [8: 58].

Nowadays fantasy is considered to be not only specific literary term but also important part of other scientific fields. Fantasy is examined and discussed not only in literary circles but it is part of other scientific disciplines as well. Fantasy as a sociological phenomenon is presented in the work by 
Anastasia Seregina, who follows the lines pointed out by Jackson and Armit who "have stressed that fantasy has no correct or absolute meaning, as it is a contextual and shifting phenomenon" and Hume, who "rejects any general definition of fantasy, describing it rather as an impulse" and Attebery who "proposes that it may be more useful to approach fantasy as a 'fuzzy set,' that is, a set of various definitions and approaches, as this allows for a more inclusive perspective" [28: 5].

Fantasy, standing out from speculative fiction into an independent genre, gradually expanded ideologically and thematically notionally. And today we can say for sure that fantasy has overgrown the concept of the literary genre by having won various forms of art. In such a way Anna Grytting speaks of the proliferation of fantasy today from purely childish writing to literature satisfying the reader's interests of any age groups [11: 4-5]. Such a wide-ranging interest is explained by the possibility to "escape into the secondary world" which Abbigail Mazour devotes her work "The Reality of Escape in Fantasy" to [23].

Purpose. Our hypothesis is that fantasy is a meta-genre which has a stable structure for modeling the fantastic world and united by a common subject of artistic representation. It has grown from the centuries-old tradition of the fantastic, actualizing and using its elements in varying degrees. The material for our research was fantasy phenomenon in its various manifestations. We trace the conditions and factors that influenced the historical process of development of fiction on the formation and development of fantasy as a meta-genre.

Results. In the situation of a primitive society myths served as the main learning style of the world cognition and in view of their syncretic nature they played a significant role in the genesis of various ideological forms, serving as the initial material for the development of philosophy, scientific ideas, literature [34: 15]. The naive hominization of the world around is typical for all of them. These ideas were a synthesis of knowledge about the surrounding reality while the inaccessible to perception was replaced by the fictional and the fantastic.

However, there is no style in the myth, it is impossible to analyze its poetics. According to A. Kichenko, "the myth is syncretic and, therefore, indivisible from the point of view of its expressive factors, and, in the first instance, it means an increased degree of semiotic character of mythological thinking" [16: 103].

Yuri Lotman, considering mythology as a complex of the "language of the proper names" in combination with creative thinking as a mythogenic substrate, emphasizes the idea of " $\mathrm{i} \mathrm{m} \mathrm{p} \mathrm{o} \mathrm{s} \mathrm{s} \mathrm{i} \mathrm{b} \mathrm{i} \mathrm{l} \mathrm{it}$ y of poetry at the mythological stage" of creative thinking (discharge of the author). The researcher points out that "poetry and myth are antipodes, each of which is possible only on the basis of denial" [20: 72-73].

In addition, speaking of poetics we mean the phenomenon of synonymy, which is excluded in mythology: "Mythological identification has a fundamentally extra-textual nature, growing on the basis of the inseparability of the name from the thing $<\ldots>$ Each name refers to a specific moment of transformation, and, therefore, they cannot replace each other in the same context." [20: 72-73].

Consequently, we can talk about the structural levels of mythology, about different motifs and heroes but not about the poetic system of expressive means in the traditional historical and literary sense of the word. In addition, this "diffusion of primitive thinking" produces "an isomorphism of the structure of outer space and the events of mythical time" [24: 164-165]. Time in the myth is cyclical; space is represented as a collection of separate objects, having nothing between. The division of the world into real and irreal is not significant, although first fantasy elements can be found in the literary works dated back to the $8^{\text {th }}$ century BC. Brian Stableford points out that at that time "the Homeric epics are recorded, establishing the notion of literary genius and launching the tradition of fantasy literature. The works of Hesiod, including the Theogony, record the wider substance of classical mythology" [30: xiii].

Folklore as the first poetic system produced first elements of the discreteness of verbal thinking: the concepts of "beginning" and "end" and elements of linearity of the temporal organization of narration. In such a way it became possible to separate the categories of "the real" and "the fantastic": there were formed the ideas about the other world as opposed to the real one.

Consequently, mythology interests us, first of all, in close connection with folklore which represents the first poetic system where the forms of creative rethinking of mythological structures were fixed. Whereas, the necessary overcoming of mythical thinking, according to A. Potebnia, occurs as a result of constant "thickening" of poetic thought, the metaphorization of the word based on the transformation of objective (mythological) verbal meanings into subjective (poetic) ones. This is the way to define figuratively generalizing priorities of the word, its movement from an external sound form to an internal symbolic one [25: 175-214].

In the Medieval period speculative fiction firmly established itself in the culture with dual semantics: positive (miracle) and negative (infernal). This tendency can be seen especially in Eastern Slavonic literatures where for quite a long period of time the dominant place was occupied by the religious Christian tradition (Orthodox): hagiography, apocrypha, tales, stories. Western European Medieval literature developed along a different path.

$\mathrm{Yu}$. Borev identifies three areas in the artistic concept of this era, each of which turned to speculative fiction in various extents: chivalrous romanticism; sacred allegorism; carnival naturalism [2: 235]. Unfortunately, we are not able to consider each of them in detail. We will only say that the Middle Ages became the starting point for the development of speculative fiction as such and along 
with the myth-folklore tradition it cherishes the content of fantastic genres in the Slavic and Western European countries. Throughout the history of literature fantasy and fantastic have been inhabiting classical literary works.

In the Baroque period fantasy synthesizes features of Medieval and Renaissance literary traditions. Its main ideas are the idea of fate and the fatality of human existence. All these items will be irrelevant in classicism when the fantastic serves as an ornament of reality.

At the end of the 18th century - at the beginning of the 19th century a new phenomenon appeared in the West European and American speculative fiction literature - the so-called novel of "horrors and secrets". Its distinctive feature was the theme and philosophy of the "world evil", the plots were usually based on mysterious crimes, the characters were marked by the seal of fate and demonism. Originally created as cheap literature later the "Gothic" novel acquired significance and enshrined in the literature of subsequent cultural eras.

In the works of romantics based on the philosophy and aesthetics of dualism, fantastic, mystical, other-world, supernatural becomes integral part of their creativity (for further information please refer to [13: 98-101]). In the period of transition from romanticism to realism, in our opinion, the fundamentals of science fiction were formed and the first works of this type were created ("The 4338th year" by V. Odoyevsky). Realism increasingly develops science fiction and actually fiction acquires the features of entertainment gradually.

Modernism tending to the romantic method, complicates the romantic perception of speculative fiction. It became complicated and filled with psychologism.

And only within the framework of postmodernism there appeared fantasy with two models, Western European and Slavonic, which we emphasize. The national myth-folklore tradition played a huge role in the development of each of them.

We understand fantasy as a super genre (metagenre) phenomenon, based on the most common definitions of a meta-genre. For example, R. Spivak suggests considering meta-genres metahistorically, that is, as "a structurally expressed, neutral in relation to the genus, a stable invariant of many historically specific means of artistic modeling of the world, united by a common subject of artistic representation" [29: 53]. In such a way fantasy can be represented in various genres belonging to any literary genre, which indicates the impossibility of a clear generic identification.

Another interpretation of the meta-genre was offered by N. Leiderman, who understands this phenomenon as a "senior genre", the one which concentrates the essential focus of the content form, particular for a group of genres. Consequently, the structural principles of the construction of the belles world of the "seniour genre" were born within the framework of a literary school or trend, becoming the core of their genre system, and then extending to more distant genres [18: 327-330]. In such a way, fantasy which had appeared initially as a genre of speculative fiction, gradually evolving, conquered new genres and developed its own subtypes.

In addition, fantasy develops in postmodernism, that is, in the literary school that emerged in the period of the collapse of a holistic world view and the destruction of ideological and philosophical systems. The information explosion that occurred in the twentieth century, generates an awareness of the impossibility of comprehending the continuous flow of knowledge. All this leads to the desire to search for other worlds where he would feel comfortable. One of the ways to realize such a desire was to turn to fantasy. From the second half of the twentieth century it performs one of the functions of fiction - escapism (escape from reality, for various reasons, into fictional worlds). For example, in the pre-romantic period this function was performed by the Gothic novel, and in the epoch of Romanticism - speculative fiction itself, which became one of the sides of worldbuilding there. And since fantasy is a rather young phenomenon, it is difficult for us to judge how productive it will be in subsequent eras, although we find its elements in the literature of previous eras.

O. Burlina proposed the definition of the metagenre in the cultural aspect, as the way of functioning of a method in the culture as its transponder [3: 44-45]. Speculative fiction in general and fantasy in particular can be created in different kinds of art: in literature, cinema, painting, sculpture (paintings by Michael Parkes, sculptures by Yuanxing Liangand, fantasy series "Games of Thrones") etc. Therefore, it is reasonable to define these phenomena not as a genre formation but as a meta-genre, which has its own history and features (as, for example, in the works by E. Galanina and D. Baturin [9] and T. Khoruzhenko [14]).

As we have said, many researchers use the category of genre in relation to fantasy. However, this is not entirely accurate, since there are fantasy novels, fantasy stories and even fantasy lyrics (as we can see on the example of. J. Tolkien's and J. Martin's creative writing). In other words, fantasy is a genre version of the novel, story, etc. Following E. Kovtun, we will agree that this is just "the meaning of a "sort", type, kind (one of many) of a literary text" [17: 4]. And the word "genre", in the opinion of the researcher, is used rather as a conditional term, bringing together works in content and the way of presentation.

And since fantasy is a young phenomenon and it does not have a long tradition, such as speculative fiction, it is difficult to make predictions about the development of this phenomenon. T. Khoruzhenko plans three main ways of development for fantasy. The first way is a possible "further development of fantasy novel, which will lead to even tougher structure of the canon, as well as the development of fantasy story and fantasy short story" [15: 110]. The 
second possible path is associated with the possible disappearance of fantasy, with its complete dissolution in mass literature and entering into other genres. The third way is a possible "formation of fantasy meta-genre" [15: 110].

Conclusion. Fantasy, a relatively new literary phenomenon, was the result of a long development of speculative fiction. It naturally separated into an independent branch and started developing actively in the second half of the twentieth century. Consequently, fantasy acquired characteristic features, such as "mythological basis, adventure intrigue, the division of the heroes into possessing superpowers and not possessing such ones, the presence of magical artefacts, opposition to the evil on a global scale" [26: 1]. Gradually having conquered various genres of literature and then other forms of art as well, fantasy transcends the framework of the genre, acquiring the value of a meta-genre in the framework of the modernist trend. However, the constant interest in this phenomenon and, as a result, its development allows us to assert that its study in the coming years will be quite promising and fruitful.

\section{References}

1. Alber, J. (2016). Unnatural Narrative: Impossible Worlds in Fiction and Drama. University of Nebraska Press.

2. Borev, Yu. B. (2002). Ehstetika. Uchebnoe posobie. Moskva: Vysshaya shkola.

3. Burlina, E. YA. (1987). Kul'tura i zhanr: metodologicheskie problemy zhanrooborazovaniya i zhanrovogo sinteza. Nauchnoe izdanie. Izd-vo Saratovskogo universiteta. Saratov.

4. Dement'eva, E.S. (2017). Slavyanskoe fehntezi kak sposob priobshcheniya detej k istorii i tradiciyam svoego naroda. Vneocherednye Lazarevskie chteniya: materialy mezhdunar. nauch. konf. 37-41.

5. Dreier, Stephanie. (2018). Old fables and their new tricks: exploring revisionist fairytale fantasy in selected texts by Cornelia Funke and Svetlana Martynchik. A dissertation submitted in partial fulfillment of the requirements for the degree of doctor of philosophy in the faculty of graduate and postdoctoral studies (Germanic studies). Vancouver: the University of British Columbia.

6. Duggan, Anne, Ph D., Haase, Donald, Ph. D, Callow, Helen J. (2016). Folktales and Fairy Tales: Traditions and Texts from around the World. 2 nd ed. 4 vols. ABC-CLIO.

7. Fairy Tale Origins Thousands of Years Old, Researchers Say. (2016). Local Live, BBC. BBC News, 20 Jan. 2016, www.bbc.com/news/uk-35358487. Accessed 6 Nov.

8. Fredrickson, N. (2016). Designing a course integrating critical pedagogy, fantasy literature, and religious studies. Fantasy Literature. Sense Publishers. 57-76.

9. Galanina, E. V., Baturin, D. A. (2016). Fehntezi kak neomifologicheskaya real'nost'. Vestnik Chelyabinskogo gosudarstvennogo universiteta. 3 (385 (39)). 41-45.

10. Grossman, Evelyne. (2016). Roland Barthes, Jacques Derrida: au-delà de la différence sexuelle. Colloque "RASTROS DO IMPENSADO: A DESCONSTRUÇÃO A LITERATURA (DE RETORNO A DERRIDA)", ([Traces de l'impensé : la déconstruction, la littérature (revenant sur Derrida)] Université de BRASILIA (Brésil), Sep 2016, Brasilia, Brésil.

11. Grytting, Anna. (2018). On the Yellow Brick Road: Fantasy, Fairy Tales, and the Coming of Age Journey. University of Agder: Faculty of Humanities and Education, Department of Foreign Languages and Translation.

12. Higgins, Andrew (2017) Building Imaginary Worlds (2012) by Mark J.P. Wolf and Revisiting Imaginary World (2016) edited by Mark J.P. Wolf, Journal of Tolkien Research: Vol. 4: Iss. 1, Article 10. Available at: http://scholar.valpo.edu/journaloftolkienresearch/vol4/iss1/10

13. Ivanova, N. P. (2014). Problema dinamiki fantasticheskogo zhanra v russkoj romanticheskoj proze 1820-h $-1830-\mathrm{h}$ godov. Naukovi praci Kam'yanec'-Podil's'kogo nacional'nogo universitetu imeni Ivana Ogienka: Filologichni nauki, 35, 98 101.

14. Khoruzhenko, T. I. (2017). Motiv Vtorogo prishestviya v sovremennoj russkoj fehntezi. Problemy istoricheskoj poehtiki. 17 (2). 141-158.

15. Khoruzhenko, T. I. (2014). Put' fehntezi: ot zhanra k metazhanru. Vestnik SurGPU. 5 (32). 107-111.

16. Kichenko, A. S. (2003). Mifopoehticheskie formy v fol'klore i istorii russkoj literatury XIX veka. Nauchnoe izdanie. Cherkassy : Izd-vo Cherkasskogo universiteta.

17. Kovtun, E. N. (2007). Fantastika kak ob"ekt nauchnogo issledovaniya: problemy i perspektivy otechestvennogo fantastovedeniya. Russkaya fantastika na perekrest'e ehpoh i kul'tur: materialy Mezhdun. nauch. konf., 21-23 marta 2006 g. 4.

18. Lejderman, N. (2010). Teoriya zhanra. Nauchnoe izdanie. Ekaterinburg: Institut filologicheskih issledovanij i obrazovatel'nyh strategij "Slovesnik" UrO RAO; UrGPU.

19. Linhardt, Abigail (2016). Rhetorically Fantastic: The Relationship Between Fantasy Literature and Academic Scholarship As Seen Through an Analysis Of The Neverending Story. Electronic Thesis or Dissertation. University of Findlay, 2016. OhioLINK Electronic Theses and Dissertations Center. 02 Nov. 2018

20. Lotman, Yu. M. Uspenskij, B. A. (1992). Mif - imya - kul'tura. Izbrannye stat'i v trekh tomah. T. I. Nauchnoe izdanie. Tallinn: "Aleksandra".

21. Lugovaya, E.A. (2015). Mifopoehticheskie osnovaniya proizvedenij zhanra "fantasy”. Gumanitarnye i yuridicheskie issledovaniya. 7679.

22. Markova, T.N. (2017). Zhanrovaya priroda romanov M. Semenovoj. Vestnik Chelyabinskogo gosudarstvennogo pedagogicheskogo universiteta. 8. 152156.

23. Mazour, A. (2018). The Reality of Escape in Fantasy. Honors Teses, University of Nebraska-Lincoln. 54. htps://digitalcommons.unl.edu/honorstheses/54.

24. Meletinskij, E. M. (1976). Poehtika mifa. Nauchnoe izdanie. Moskva: Nauka. 
25. Potebnya, A. A. (1976). Estetika i poehtika. Nauchnoe izdanie. Moskva: Iskusstvo.

26. Ryzhchenko, Olga. Problems of definition and classification of fantasy: Western European and Slavonic perspectives. SHS Web of Conferences. - 2018. - Vol. 55. - 04009. - Pp. 1-7.

27. Safron, E. A. (2017). Traditions of Urban Fantasy in M. Yu. Lermontov's Novella "Stoss". Vestnik Severnogo (Arkticheskogo) federal'nogo universiteta. Ser.: Gumanitarnye i sotsial'nye nauki. 1. 131-138.

28. Seregina, A. (2018). Performing fantasy and reality in contemporary culture. Taylor\&Francis Ltd, Routledge.

29. Spivak, R. (1985). Russkaya filosofskaya lirika: problemy tipologii zhanrov. Nauchnoe izdanie. Krasnoyarsk: Izd-vo Krasnoyar. un-ta.

30. Stableford, Brian. (2005). Historical Dictionary of Fantasy Literature. Toronto: The Scarecrow Press. Inc. Lanham, Maryland.

31. Steinseifer-Szabo, J. (2015). Is fantasy a central genre in modern literature? GRIN Publishing Apr.

32. Svein, A. (2005). Policing Fantasy: Problems of Genre in Fantasy Literature. A Thesis presented to The Department of Literature Area Studies and European Languages. The University of Oslo.

33. Tolkachyova, V.S. (2010). Fehntezi: zhanr ili literaturnoe napravlenie? Izvestiya Volgogradskogo Gosudarstvennogo Pedagogicheskogo universiteta. 169172.

34. Tokarev, S. A. (1988). Mify narodov mira. Sovetskaya ehnciklopediya. 1.: A-K. 15.

35. Zaja, P.M. (2018). Beyond and Below: Subversive Spaces in Postmodern British Fantasy. A Thesis Submitted to the Faculty of Purdue University in Partial Fulfillment of the Requirements for the degree of Master of Arts. Department of English. Hammond, Indiana.

Іванова Наталія Петрівна, кандидат філологічних наук, старший викладач кафедри російської мови, зарубіжної літератури та методики навчання, Черкаський національний університет імені Богдана Хмельницького (м. Черкаси, бульвар Шевченка, 81, 18031); e-mail: nathal3 @ukr.net; https://orcid.org/0000-0002-9558-9764

Иванова Наталья Петровна, кандидат филологических наук, старший преподаватель кафедры русского языка, зарубежной литературы и методики обучения, Черкасский национальный университет имени Богдана Хмельницкого (г. Черкассы, бульвар Шевченко, 81, 18031) e-mail: nathal3@ukr.net; https://orcid.org/0000-0002-9558-9764

Ivanova Nataliya Petrovna, the Assistant Professor of School of the Russian Language, World Literature and Methods of Teaching, Ph.D. in Philology, Bohdan Khmelnitsky National University of Cherkasy (Shevchenko Avenue 81, Cherkasy 1803181); e-mail: nathal3@ukr.net; https://orcid.org/0000-0002-9558-9764

Рижченко Ольга Сергіївна, кандидат філологічних наук, старший викладач кафедри мовної підготовки Харківського національного університету радіоелектроніки (м. Харків, просп. Науки, 14, 61166); e-mail: eradis80@rambler.ru; https://orcid.org/00000003-1693-6121

Рыжченко Ольга Сергеевна, кандидат филологических наук, старший преподаватель кафедры языковой подготовки Харьковского национального университета радиоэлектроники (г. Харьков, просп. Науки, 14, 61166); e-mail: eradis80@ rambler.ru; https://orcid.org/0000-0003-1693-6121

Ryzhchenko Olga Sergeevna, the Assistant Professor of Language Training department, Ph.D. in Philology, Kharkiv National University of Radio Electronics (Nauky Avenue 14, Kharkiv, 61166); e-mail: eradis80@ rambler.ru; https://orcid.org/0000-0003-1693-6121 